\title{
THE SEASONAL EFFECTS OF DECIDUOUS TREE FOLIAGE IN CORS-GNSS MEASUREMENTS (VRS/FKP)
}

\begin{abstract}
Atinc Pirti
Original scientific paper This article examines the performance and use of GNSS based data acquisition systems in the seasonal effects of deciduous tree foliage. As a general rule, a clear view of the sky is preferred when using GNSS for determining location. Season in the case of deciduous trees is the parameter affecting GNSS signal attenuation. As a result of this attenuation, positions computing weak signals tend to be less accurate. This means that using GNSS in forest is one of the most demanding uses of technology and one that requires particular attention when evaluating GNSS receivers that will be used in such an environment. This paper evaluates GNSS positional accuracy, precision and performance in the forest area. The obtained horizontal differences for three baselines in April between CORS-VRS/FKP and Total station survey results are $\pm(1 \div 3) \mathrm{cm}$. The height differences obtained for three baselines in April between CORS-FKP and Total station survey results are $\pm(2 \div 4) \mathrm{cm}$.
\end{abstract}

Keywords: accuracy; CORS; FKP; GNSS; RTN; season; VRS

Sezonski učinci lišća listopadnog drveća u CORS-GNSS mjerenjima (VRS/FKP)

Izvorni znanstveni članak U ovom se članku istražuje učinkovitost i uporaba sustava prikupljanja podataka temeljenih na GNSS u sezonskim učincima lišća listopadnog drveća. Kao opće pravilo, poželjan je jasan pogled na nebo kada rabimo GNSS za određivanje položaja. Sezona u slučaju bjelogorice je parametar koji utječe na prigušenja GNSS signala. Kao rezultat ovog prigušenja, pozicije koje izračunavaju slabe signale manje su točne. To znači da je uporaba GNSS u šumi jedna od najzahtjevnijih uporaba ove tehnologije i ona koja zahtijeva posebnu pozornost prilikom ocjenjivanja GNSS prijamnika koji će se rabiti u takvom okruženju. U radu se procjenjuje GNSS položajna točnost, preciznost i učinkovitost u šumskom području. Dobivene horizontalne razlike za tri polazišta u travnju između CORS-VRS/FKP i ukupnog rezultata nadzorne stanice su $\pm(1 \div 3) \mathrm{cm}$. Dobivene visinske razlike za tri polazišta u travnju između CORSFKP i ukupnog rezultata nadzorne stanice $\mathrm{su} \pm(2 \div 4) \mathrm{cm}$.

Ključne riječi: CORS; FKP; GNSS; RTN; sezona; točnost; VRS

\section{Introduction}

GNSS (GPS/GLONASS) has been applied successfully in many areas of the forest industry. Typical applications include fire prevention and control, harvesting operations, insect infestation, boundary determination, and aerial spraying. With thousands of fires facing the forest service's every year, an efficient resource-management system is essential. GNSS is a key technology that enables the system operator to identify and monitor the exact location of the resources. With the help of GIS and a good communication system, appropriate decisions can be made. GNSS has also been a very useful tool for wildlife management and insect infestation. Using its precise positioning capability, GNSS can determine the locations of activity centres. These locations can be easily accessed using GNSS waypoint navigation $[1,2,9,10]$.

It is known that tree canopies adversely affect the accuracy of GPS positioning because they attenuate GPS signals. Many studies have shown the performance of the GPS in forested areas. Martin et al. [5] evaluated DGPS positional accuracy and precision on Irish forest roads with typical peripheral canopies and discussed the relationship between position dilution of precision (PDOP) and the percentage of open sky. This study also showed that both DGPS accuracy and precision improved with decreasing peripheral obstruction. Næsset [8] showed that the accuracy of GPS positioning was significantly higher with the 12-channel GPS receiver than with the 6-channel GPS receiver and was significantly higher with the combined use of the $\mathrm{C} / \mathrm{A}$ code and carrier phase than with the use of the $\mathrm{C} / \mathrm{A}$ code only. Kobayashi et al. [3] evaluated five GPS receivers' performance by comparing the positional accuracy of the autonomous GPS, real-time DGPS, and carrier phase GPS. Results indicated that the autonomous GPS and real-time DGPS produced positional errors of $(15,4 \div$ $48,6) \mathrm{m}$ and $(2,7 \div 21,7) \mathrm{m}$, respectively, which were based on the condition that SA was on. Sawaguchi et al. [14] discussed the effect of stand conditions on positioning precision with real-time DGPS and found factors that affected positional precision by using multiple regression analysis. Mori and Takeda [6] showed the effects of SA removal on positional accuracy of the DGPS. However, Sawaguchi et al. [14] and Mori and Takeda [6] partially discussed accuracy in forested areas under different peripheral conditions after SA was turned off. Many other studies were done when SA was on. In addition, almost all studies discussed only horizontal errors of GPS positioning but not vertical errors. The main effect of forest canopy is signal obstruction. Signals are either completely blocked (for example by tree trunks or steep stream banks), or they are so weakened by passing through foliage that the receiver cannot use them anyway. This means that fewer satellites are available to the receiver. As a result of the effects of forest canopy is that they can significantly degrade the accuracy of GNSS positions. The signals are affected by the canopy and this of course affects the quality of the computed position. Forest canopy effects on the GNSS signal include obstruction, attenuation, and reflection. The GNSS signal is a line-of-sight signal and is obstructed by most solid objects. The signal is blocked by the trunks of trees, larger branches, and terrain features such as mountains or local gullies. The main effect of signal obstruction is to 
increase the Dilution of Position. This is especially true of the vertical DoP (VDOP)-and hence the three dimensional PDOP. Often in forested conditions the HDOP is acceptable when the PDOP is not. This attenuation can make it very difficult for a GNSS receiver to track the signals. At some point, the receiver will not be able to track at all and the effect will be the same as if the signal were obstructed. Even if the signal can be tracked, some receivers will have difficulty accurately measuring the pseudo ranges. Like light waves, signals will be reflected by solid objects they cannot pass through. The phenomenon of a satellite signal reaching an antenna by more than one path (direct and some reflected paths) is called multipath. This multipath can cause large variations in position and is perhaps the largest cause of large errors in position fixes under forest canopy $[1,9,10,11]$.

RTK surveying is a relative positioning technique which measures the position of two GNSS antennas relative to each other in real-time. One antenna is setup on a static point with fixed coordinates and is known as the base station. The RTK base station transmits its raw observations to the rover(s) in real-time and the rover uses both the rover and base observations to compute its position relative to the base. RTK has proven to be a reliable and efficient means for determining precise relative baselines. However, this method is limited to baselines of approximately $10 \div 20 \mathrm{~km}$ due to the effect that distance related errors (atmosphere, and satellite orbits) have on the ambiguity resolution (initialization), and solution precision. The precision of RTK decreases as the baseline length increases. Real Time Network (RTN) surveying has been developed to overcome this base-torover range limitation. The RTN concept is that a group of reference or base stations will collect GNSS observations and send them in real-time to a central processing system. The central processor will then combine the observations from all (or subset) of the reference stations and compute a network solution. From this network solution the observation errors and their corrections are computed and broadcast to rovers working within the bounds of the RTN. There are several different RTN approaches in use including the virtual reference station (VRS), master auxiliary concept (MAC), and FlächenKorrektur Parameter (FKP). The VRS technique uses the complex filter static model for the complete network to compute a virtual reference station dataset at a location near the rover. Today, more than $95 \%$ of the network RTK initializations are using the VRS technique to transport the correction stream in standardized formats (RTCM 2.3, RTCM 3.0 or CMR) from the server to the field user. All major geodetic receiver manufacturers support these formats. In addition to the compatibility with all modern geodetic receiver types, the VRS technique has an advantage in that server, using the latest model for all error sources, can continuously optimize the correction stream for each rover position. Since these error models are updated every second on a continuous $24 / 7$ basis, every rover connection into the system benefits from the optimal model immediately after a connection with the server is established. The VRS method requires bidirectional communication, which is available via GSM, GPRS and other cell phone-based data transmission methods. Today, more than $99 \%$ of the worldwide network RTK installations are using bidirectional communication technologies. A few years ago, the SAPOS (Satellite Positioning) community in Germany introduced a method for broadcasting network correction streams called 'FKP'. The acronym FKP stands for the German word 'Flaechenkorrekturparameter' which means area correction parameters. Within SAPOS, the providers agreed to standardize on RTCM 2.3 with a proprietary extension via a type 59 message. This additional message describes the linear ionospheric and geometric correction around a physical reference station. The software derives linear approximations from the complex filter state vector for the ionospheric and geometric effects. These linear parameters describe changes in the effects in the North-South and East-West directions. Since using a linear model is a very simplified method, the FKP parameters can only be used for a very limited area surrounding a single reference station. Today less than $5 \%$ of the worldwide network RTK installations are using the FKP method. Even within the SAPOS community, the method of choice for most of the users is VRS. While FKP was designed for use in a broadcast mode, most of the installations are using it in bidirectional mode with GSM and GPRS. This is due mainly to the advantages in larger networks of the VRS technique that also has an added benefit in that bidirectional communications allow user access control and user accounting. VRS and FKP messages are used in conjunction with the RTCM 2.3, RTCM 3.0 and CMR industry standardized formats. Both methods use a special message to indicate to the rover that the data is derived from a network server and to provide additional information on ionospheric and geometric error components in the area near the rover location. These messages, and their implementation in RTCM 2.3, were communicated to all rover receiver manufacturers. As a result, all the major geodetic receiver manufacturers are providing rover solutions compatible with the VRS and FKP data formats. While this extra message is defined for FKP in RTCM 2.3 only, this extra message is available in RTCM 2.3, RTCM 3.0 and CMR for the VRS technique. While the VRS method is the most common technique used worldwide, the RTCM committee is currently discussing a network proposal for broadcast transmission of network RTK corrections that will be useful with radio systems and internet-based multicast solutions $[1,4,9$, $12,15,16]$. The aim of this study is to investigate that season in the case of deciduous trees (leaf-off and leaf on) is a very important parameter for GNSS accuracy and productivity.

\section{Material and methods}

The study was performed in Yildiz Technical University Campus, in Davutpasa Region of Istanbul, Turkey (Fig. 1). A geodetic network consisting of 3 stations (P1, P2 and P3) was measured using CORS (Continuously Operating Reference Station), static and terrestrial measurement methods. To study the foliage effects on a baseline, the three points (P1, P2 and P3) were situated under the tree areas consisting of coniferous trees, see Fig. 2. These three stations (P1, P2 and P3) were located at a distance of about $5 \mathrm{~m}, 10 \mathrm{~m}$ in the forest 
area consisting of around $(8 \div 10) \mathrm{m}$ tall larix pine trees. The CORS RTK, static data were collected on P1, P2 and P3 by using Topcon Hiper Pro and three Ashtech Z Max GPS receivers, respectively. The minimum elevation cutoff angle was 10 degrees; the data was collected for $\sim 3$ hours (static) with a sampling rate interval of 30 seconds for static measurements of these three points.

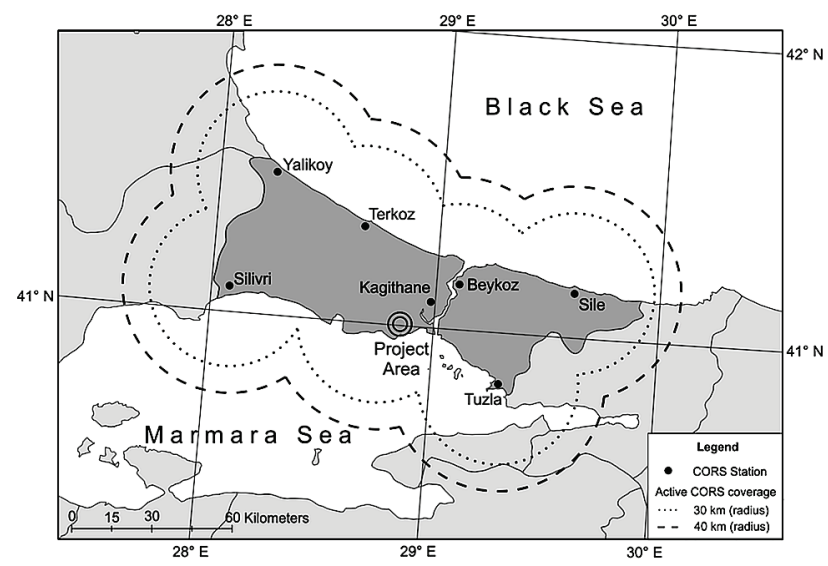

Figure 1 Project area and ISKI CORS stations in Istanbul

\section{Results}

\subsection{Static processing of GNSS data}

Static data collection produces the most accurate and reliable results due to the amount of data collected during each observation. The disadvantage is in productivity. Long observations at each point reduce the number of points that can be collected in a day. The static measurements were taken both in the loss of leaves (April 17, 2012-Day of Year-DOY 108) and in the presence of leaves (June 1, 2012- Day of Year- DOY 153). The RINEX data were processed with Ashtech Solution 2.60 Software in order to compute the coordinates of P1, P2 and P3 for both sessions in ITRF 2008 on both days (see Tabs. 1 and 2). In the adjustment procedure, the ITRF 2008 coordinates of PALA (İSKI CORS Station) were taken fixed. The distance from PALA to the points in the project area is approximately $9,1 \mathrm{~km}$, see Fig. 1.

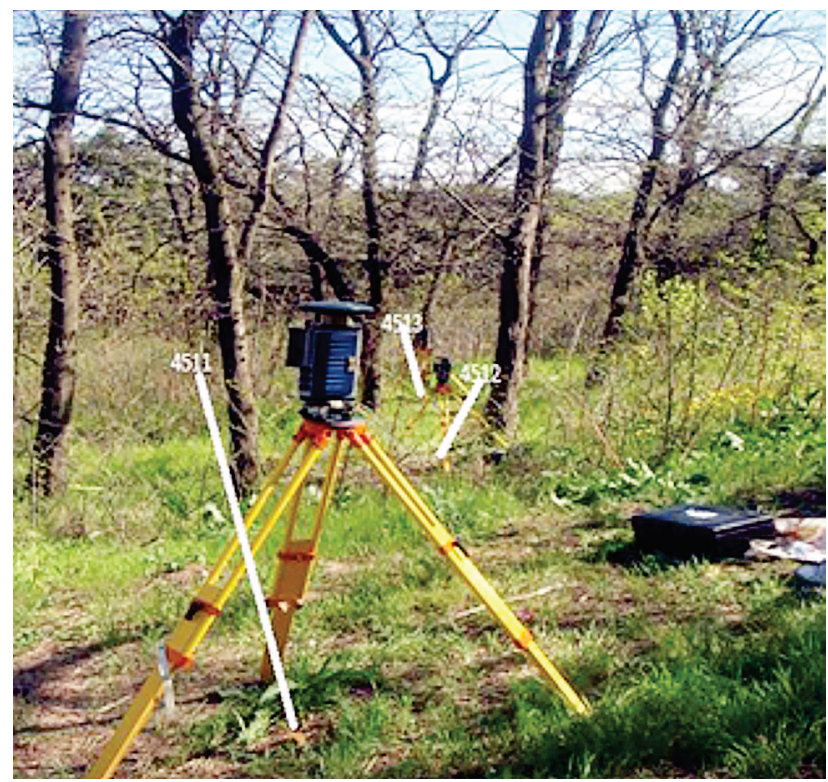

Figure 2 The three points in the project area (April 17, 2012)
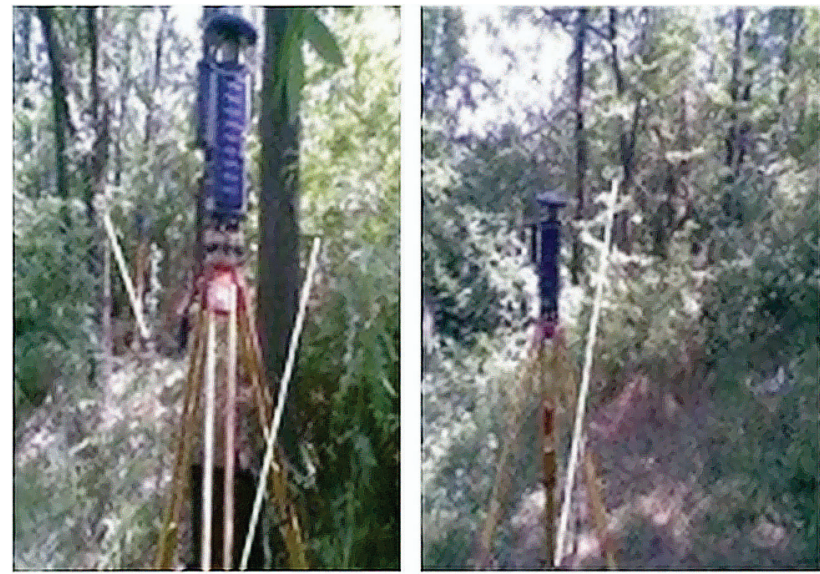

Figure 3 The three points in the project area (June 1, 2012)

Table 1 The results of the L1\&L2 static processing by using the three Ashtech Z Max GPS receivers in 17 April 2012

\begin{tabular}{|c|c|c|c|c|c|}
\hline Point & $\varphi$ & Std / mm & $\lambda$ & Std / mm & $h$ \\
\hline PALA & $41^{\circ} 05^{\prime} 10,76556^{\prime \prime}$ & 0 & $28^{\circ} 57^{\prime} 47,52420^{\prime \prime}$ & 0 & 170,561 \\
\hline 1 & $41^{\circ} 01^{\prime} 18,27374^{\prime \prime}$ & 3 & $28^{\circ} 53^{\prime} 47,45192^{\prime \prime}$ & 0 & 4 \\
\hline 2 & $41^{\circ} 01^{\prime} 17,99841^{\prime \prime}$ & 3 & $28^{\circ} 53^{\prime} 47,67692^{\prime \prime}$ & 91,690 & 4 \\
\hline 3 & $41^{\circ} 01^{\prime} 17,78499^{\prime \prime}$ & 3 & $28^{\circ} 53^{\prime} 47,88401^{\prime \prime}$ & 90,370 & 6 \\
\hline
\end{tabular}

Table 2 The results of the L1\&L2 static processing by using the three Ashtech Z Max GPS receivers in 1 June 2012

\begin{tabular}{|c|c|c|c|c|c|c|}
\hline Point & $\varphi$ & Std / mm & $\lambda$ & Std / mm & $h$ & $S t d / \mathrm{mm}$ \\
\hline PALA & $41^{\circ} 05^{\prime} 10,76556^{\prime \prime}$ & 0 & $28^{\circ} 57^{\prime} 47,52420^{\prime \prime}$ & 0 & 170,561 & 0 \\
\hline 1 & $41^{\circ} 01^{\prime} 18,27403^{\prime \prime}$ & 11 & $28^{\circ} 53^{\prime} 47,45104^{\prime \prime}$ & 13 & 91,710 & 19 \\
\hline 2 & $41^{\circ} 01^{\prime} 17,99868^{\prime \prime}$ & 11 & $28^{\circ} 53^{\prime} 47,67663^{\prime \prime}$ & 13 & 90,376 & 19 \\
\hline 3 & $41^{\circ} 01^{\prime} 17,78528^{\prime \prime}$ & 11 & $28^{\circ} 53^{\prime} 47,88312^{\prime \prime}$ & 13 & 90,155 & 19 \\
\hline
\end{tabular}

In summer, tree cover may be much thicker than in spring. The density of the foliage in June is much higher than in April, see Figs. 2 and 3. The signal attenuation of a deciduous tree in full foliage is greater in $\mathrm{dB}$ than that of a deciduous tree without foliage. Thus, the bulk of trees attenuation is clearly caused by the wood tree limbs, branches, and trunk rather than by leaves. It has also been shown that the attenuation of deciduous trees in full foliage in June is greater than that of deciduous trees without foliage in March. As a result of this attenuation, positions have computed weak signals and they tend to be less accurate. The effects of forest canopy (deciduous trees) and the season (survey time) can significantly degrade the accuracy of GNSS position; see in Tabs. 1 
and 2. The standard deviation values of the measurements in June are great but in April these values are not great. On the other hand, loop closure can be a very important identifier of blunders. When closed loops are selected and their closures calculated, particular vectors can easily be identified as degrading the misclose and therefore eliminated from further adjustments. The loop closures for L1\&L2 static processing in June and in April are compared with each other, see Tabs. 3 and 4. The value of the loop closure for L1\&L2 processing in April is between $5 \mathrm{~mm}$ and $13 \mathrm{~mm}$. However, the value of the loop closure for L1\&L2 processing in June is between 10 $\mathrm{mm}$ and $30 \mathrm{~mm}$. The results show that accurate coordinates are obtained by using L1\&L2 processing technique in April in this experiment.

Tab. 5 shows the coordinates and standard deviation values for the points of P1, P2, and P3 in 1 June 2012 for L1 static processing. Tab. 2 shows the coordinates and standard deviation values for the points of P1, P2 and P3 for L1 \& L2 static processing. In Tabs. 2 and 5, the coordinates and standard deviations of three points are different from each other. The coordinates and standard deviation values of the three points are equal to those in both L1 (Tab. 5) and L1\&L2 (Tab. 1) processing. The value of the loop closure for L1 processing in June is between $8 \mathrm{~mm}$ and $19 \mathrm{~mm}$.

Table 3 The loop closure for L1\&L2 static processing of the network in 17.04.2012

\begin{tabular}{|c|c|c|c|c|c|c|c|}
\hline $\begin{array}{c}\text { Loop } \\
\text { number }\end{array}$ & $\begin{array}{l}\text { Vectors } \\
\text { in loop }\end{array}$ & $\begin{array}{c}\text { Observed } \\
17.04 .2012 \\
\end{array}$ & $\begin{array}{c}\text { Loop } \\
\text { length/m }\end{array}$ & $\begin{array}{c}X \\
\text { misclosure/m }\end{array}$ & $\begin{array}{c}Y \\
\text { misclosure/m }\end{array}$ & $\begin{array}{c}Z \\
\text { misclosure/m }\end{array}$ & $\begin{array}{c}\text { Length } \\
\text { misclosure/ } \mathrm{m}\end{array}$ \\
\hline \multirow{3}{*}{ Loop 1} & PALA-1 & $12: 24: 45$ & 18220,839 & $-0,008$ & $-0,004$ & $-0,006$ & 0,011 \\
\hline & $1-2$ & $12: 56: 20$ & & & & & \\
\hline & PALA-2 & $12: 56: 20$ & & & & & \\
\hline \multirow{3}{*}{ Loop 2} & PALA-1 & $12: 24: 45$ & 18231,210 & $-0,007$ & 0,005 & 0,000 & 0,008 \\
\hline & $1-3$ & $12: 29: 40$ & & & & & \\
\hline & PALA-3 & $12: 29: 40$ & & & & & \\
\hline \multirow{3}{*}{ Loop 3} & PALA-2 & $12: 56: 20$ & 18224,643 & 0,001 & 0,008 & 0,010 & 0,013 \\
\hline & $3-2$ & $12: 56: 20$ & & & & & \\
\hline & PALA-3 & $12: 29: 40$ & & & & & \\
\hline \multirow{3}{*}{ Loop 4} & $1-3$ & $12: 29: 40$ & 36,462 & $-0,000$ & $-0,001$ & 0,004 & 0,005 \\
\hline & $1-2$ & $12: 56: 20$ & & & & & \\
\hline & $2-3$ & $12: 56: 20$ & & & & & \\
\hline
\end{tabular}

Table 4 The loop closure for L1\&L2 static processing of the network in 01.06.2012

\begin{tabular}{|c|c|c|c|c|c|c|c|}
\hline $\begin{array}{c}\text { Loop } \\
\text { number }\end{array}$ & $\begin{array}{l}\text { Vectors } \\
\text { in loop }\end{array}$ & $\begin{array}{c}\text { Observed } \\
01.06 .2012\end{array}$ & $\begin{array}{c}\text { Loop } \\
\text { length/m }\end{array}$ & $\begin{array}{c}X \\
\text { misclosure/ m }\end{array}$ & $\begin{array}{c}Y \\
\text { misclosure/ m }\end{array}$ & $\begin{array}{c}Z \\
\text { misclosure/m }\end{array}$ & $\begin{array}{c}\text { Length } \\
\text { misclosure/ m }\end{array}$ \\
\hline \multirow{3}{*}{ Loop 1} & PALA-1 & $09: 12: 45$ & 18220,837 & $-0,013$ & $-0,002$ & $-0,005$ & 0,014 \\
\hline & $1-2$ & 09:18:00 & & & & & \\
\hline & PALA-2 & 09:18:00 & & & & & \\
\hline \multirow{3}{*}{ Loop 2} & PALA-1 & $09: 12: 45$ & 18231,222 & $-0,016$ & 0,015 & 0,013 & 0,026 \\
\hline & $1-3$ & $09: 15: 35$ & & & & & \\
\hline & PALA-3 & $09: 15: 35$ & & & & & \\
\hline \multirow{3}{*}{ Loop 3} & PALA-2 & 09:18:00 & 18224,639 & 0,004 & $-0,013$ & $-0,027$ & 0,030 \\
\hline & $3-2$ & 09:18:00 & & & & & \\
\hline & PALA-3 & 09:15:35 & & & & & \\
\hline \multirow{3}{*}{ Loop 4} & $1-3$ & $09: 15: 35$ & 36,458 & 0,000 & $-0,004$ & $-0,009$ & 0,010 \\
\hline & $1-2$ & 09:18:00 & & & & & \\
\hline & $2-3$ & 09:18:00 & & & & & \\
\hline
\end{tabular}

Table 5 The results of the L1 static processing the GNSS network

\begin{tabular}{|c|c|c|c|c|c|c|}
\hline Point & $\varphi$ & $S t d / \mathrm{mm}$ & $\lambda$ & $\mathrm{Std} / \mathrm{mm}$ & $h$ & Std / mm \\
\hline PALA & $41^{\circ} 05^{\prime} 10,76556^{\prime \prime}$ & 0 & $28^{\circ} 57^{\prime} 47,52420^{\prime \prime}$ & 0 & 170,561 & 0 \\
\hline 1 & $41^{\circ} 01^{\prime} 18,27423^{\prime \prime}$ & 6 & $28^{\circ} 53^{\prime} 47,45158^{\prime \prime}$ & 6 & 91,724 & 11 \\
\hline 2 & $41^{\circ} 01^{\prime} 17,99883^{\prime \prime}$ & 6 & $28^{\circ} 53^{\prime} 47,67690^{\prime \prime}$ & 6 & 90,393 & 11 \\
\hline 3 & $41^{\circ} 01^{\prime} 17,78529^{\prime \prime}$ & 6 & $28^{\circ} 53^{\prime} 47,88342^{\prime \prime}$ & 6 & 90,149 & 11 \\
\hline
\end{tabular}

To compare the results of GNSS measurements with those of independent measurement method, the distance was measured between the points using a total station. The terrestrial measurements were performed using NIKON DTM-322 (angle accuracy: \pm 5 , distance measurement accuracy: $3 \mathrm{~mm}+2 \mathrm{ppm})$. Distance and height measurements were taken ( 5 series) and the mean values of all measurements were calculated. The quality of the results can be assessed by comparison with the spatial distances determined by the terrestrial measurements. The GNSS distances were calculated from the coordinates obtained from the GNSS measurements and compared with the distances obtained by using the total station, see Tab. 7. The height differences obtained by using total station were also compared to ellipsoidal height differences obtained from the GNSS, see Tab. 7. The variation of the geoid was neglected since the distances are very short. It appears from this comparison of the results in GNSS with terrestrial measurements at the Davutpasa Region that the variations are greater in height differences and smaller in distances. The horizontal differences obtained for three baselines in April between static GNSS and Total station survey results are $\pm(1 \div 2)$ $\mathrm{mm}$. The height differences obtained for three baselines in 
April between static GNSS and Total station survey results are $\pm(8 \div 42) \mathrm{mm}$. On the other hand, the horizontal differences for three baselines in June between static GNSS and Total station survey results are $\pm(1 \div 8) \mathrm{mm}$. The height differences obtained for three baselines in June between static GNSS and Total station survey results are $\pm(20 \div 54) \mathrm{mm}$, see Tab. 7. The horizontal differences obtained for three baselines in April between CORS-VRS and Total station survey results are $\pm(6 \div 24) \mathrm{mm}$. The height differences obtained for three baselines in April between CORS-VRS and Total station survey results are $\pm(20 \div 30) \mathrm{mm}$. On the other hand, the horizontal differences obtained for three baselines in June between CORS-VRS and Total station survey results are $\pm(8 \div 31)$ $\mathrm{mm}$. The height differences obtained for three baselines in June between CORS-VRS and Total station survey results are $\pm(19 \div 68) \mathrm{mm}$, see Tab. 8 .The horizontal differences obtained for three baselines in April between CORS-FKP and Total station survey results are $\pm(13 \div 16) \mathrm{mm}$. The height differences obtained for three baselines in April between CORS-FKP and Total station survey results are \pm $(17 \div 34) \mathrm{mm}$. On the other hand, the horizontal differences obtained for three baselines in June between CORS-FKP and Total station survey results are $\pm(16 \div 41)$ $\mathrm{mm}$. The height differences obtained for three baselines in June between CORS-FKP and Total station survey results are $\pm(13 \div 36) \mathrm{mm}$, see Tab. 9 . The obtained results in this study are consistent with those of many other groups that made similar tests. The horizontal and vertical accuracy in obstructed areas discussed in this paper are in agreement with those of the other authors.

Table 6 The loop closure for L1 static processing of the GNSS network

\begin{tabular}{|c|c|c|c|c|c|c|c|}
\hline $\begin{array}{l}\text { Loop } \\
\text { number }\end{array}$ & $\begin{array}{l}\text { Vectors } \\
\text { in loop }\end{array}$ & $\begin{array}{c}\text { Observed } \\
01.06 .2012 \\
\end{array}$ & $\begin{array}{c}\text { Loop } \\
\text { length/m }\end{array}$ & $\begin{array}{c}X \\
\text { misclosure/m }\end{array}$ & $\begin{array}{c}Y \\
\text { misclosure/m }\end{array}$ & $\begin{array}{c}Z \\
\text { misclosure/m } \\
\end{array}$ & $\begin{array}{c}\text { Length } \\
\text { misclosure/ } \mathrm{m}\end{array}$ \\
\hline \multirow{3}{*}{ Loop 1} & PALA-1 & $09: 12: 45$ & 18220,831 & $-0,002$ & 0,000 & $-0,008$ & 0,008 \\
\hline & $1-2$ & 09:18:00 & & & & & \\
\hline & PALA-2 & 09:18:00 & & & & & \\
\hline \multirow{3}{*}{ Loop 2} & PALA-1 & $09: 12: 45$ & 18231,211 & $-0,012$ & 0,001 & $-0,002$ & 0,012 \\
\hline & $1-3$ & $09: 15: 35$ & & & & & \\
\hline & PALA-3 & $09: 15: 35$ & & & & & \\
\hline \multirow{3}{*}{ Loop 3} & PALA-2 & 09:18:00 & 18224,630 & $-0,019$ & $-0,005$ & $-0,001$ & 0,019 \\
\hline & $3-2$ & 09:18:00 & & & & & \\
\hline & PALA-3 & $09: 15: 35$ & & & & & \\
\hline \multirow{3}{*}{ Loop 4} & $1-3$ & $09: 15: 35$ & 36,467 & 0,005 & $-0,001$ & $-0,002$ & 0,005 \\
\hline & $1-2$ & 09:18:00 & & & & & \\
\hline & $2-3$ & 09:18:00 & & & & & \\
\hline
\end{tabular}

Table 7 The comparison of static GNSS and Total Station survey results for three baselines

\begin{tabular}{|c|c|c|c|c|c|c|c|c|c|c|}
\hline & \multicolumn{4}{|c|}{ Static GNSS } & \multicolumn{2}{|c|}{ Total Station } & \multicolumn{2}{|c|}{ 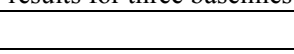 } & \multirow{2}{*}{\multicolumn{2}{|c|}{ April }} \\
\hline & \multicolumn{2}{|c|}{ June } & \multicolumn{2}{|c|}{ April } & \multirow[b]{2}{*}{$S / \mathrm{m}$} & \multirow[b]{2}{*}{$\mathrm{d} h / \mathrm{m}$} & \multicolumn{2}{|c|}{ June } & & \\
\hline & $S / \mathrm{m}$ & $\mathrm{d} h / \mathrm{m}$ & $S / \mathrm{m}$ & $\mathrm{d} h / \mathrm{m}$ & & & $\Delta S / \mathrm{m}$ & $\Delta h / \mathrm{m}$ & $\Delta S / \mathrm{m}$ & $\Delta h / \mathrm{m}$ \\
\hline $1-2$ & 10,085 & 1,334 & 10,076 & 1,320 & 10,078 & 1,354 & 0,007 & $-0,020$ & $-0,002$ & $-0,034$ \\
\hline $1-3$ & 18,211 & 1,555 & 18,213 & 1,567 & 18,212 & 1,609 & $-0,001$ & $-0,054$ & 0,001 & $-0,042$ \\
\hline $2-3$ & 8,165 & 0,221 & 8,174 & 0,247 & 8,173 & 0,255 & $-0,008$ & $-0,034$ & 0,001 & $-0,008$ \\
\hline
\end{tabular}

Table 8 The comparison of CORS-VRS and Total Station survey results for three baselines

\begin{tabular}{|c|c|c|c|c|c|c|c|c|c|c|}
\hline & \multicolumn{4}{|c|}{ VRS (Topcon HiperPro) } & \multicolumn{2}{|c|}{ Total Station } & \multirow{2}{*}{\multicolumn{2}{|c|}{ June }} & \multirow{2}{*}{\multicolumn{2}{|c|}{ April }} \\
\hline & \multicolumn{2}{|c|}{ June } & \multicolumn{2}{|c|}{ April } & & & & & & \\
\hline & $S / \mathrm{m}$ & $\mathrm{d} h / \mathrm{m}$ & $S / \mathrm{m}$ & $\mathrm{d} h / \mathrm{m}$ & $S / \mathrm{m}$ & $\mathrm{d} h / \mathrm{m}$ & $\Delta S / \mathrm{m}$ & $\Delta h / \mathrm{m}$ & $\Delta S / \mathrm{m}$ & $\Delta h / \mathrm{m}$ \\
\hline $1-2$ & 10,109 & 1,335 & 10,094 & 1,374 & 10,078 & 1,354 & $-0,031$ & 0,019 & $-0,016$ & $-0,020$ \\
\hline $1-3$ & 18,242 & 1,658 & 18,236 & 1,639 & 18,212 & 1,609 & $-0,030$ & $-0,049$ & $-0,024$ & 0,030 \\
\hline $2-3$ & 8,165 & 0,323 & 8,179 & 0,229 & 8,173 & 0,255 & 0,008 & $-0,068$ & $-0,006$ & 0,026 \\
\hline
\end{tabular}

Table 9 The comparison of CORS-FKP and Total Station survey results for three baselines

\begin{tabular}{|c|c|c|c|c|c|c|c|c|c|c|}
\hline & \multicolumn{4}{|c|}{ FKP (Topcon HiperPro) } & \multicolumn{2}{|c|}{ Total Station } & \multirow{2}{*}{\multicolumn{2}{|c|}{ June }} & \multirow{2}{*}{\multicolumn{2}{|c|}{ April }} \\
\hline & & & & & & & & & & \\
\hline & $S / \mathrm{m}$ & $\mathrm{d} h / \mathrm{m}$ & $S / \mathrm{m}$ & $\mathrm{d} h / \mathrm{m}$ & $S / \mathrm{m}$ & $\mathrm{d} h / \mathrm{m}$ & $\Delta S / \mathrm{m}$ & $\Delta h / \mathrm{m}$ & $\Delta S / \mathrm{m}$ & $\Delta h / \mathrm{m}$ \\
\hline $1-2$ & 10,094 & 1,377 & 10,091 & 1,371 & 10,078 & 1,354 & $-0,016$ & $-0,023$ & $-0,013$ & $-0,017$ \\
\hline $1-3$ & 18,253 & 1,645 & 18,226 & 1,643 & 18,212 & 1,609 & $-0,041$ & $-0,036$ & $-0,014$ & $-0,034$ \\
\hline $2-3$ & 8,196 & 0,268 & 8,189 & 0,281 & 8,173 & 0,255 & 0,023 & $-0,013$ & $-0,016$ & $-0,026$ \\
\hline
\end{tabular}

\section{Conclusion}

The effects of forest canopy (deciduous trees), season in the case of deciduous trees decrease the accuracy of GNSS positions. The signals are affected by the canopy and this of course affects the quality of the computed position. This study was performed in April and in June, the foliage and density of the deciduous trees increases in
June, survey with GNSS in the forest will become increasingly difficult. It is clear that deciduous trees in June (the density of foliage) cause much more signal attenuation. CORS (VRS/FKP) data collection has the advantage of high productivity, but it has some disadvantages. Accuracy is not as good as with static data collection. The impact of the bad signal quality on the positioning results is naturally worse for CORS 
(VRS/FKP) positioning than for static processing. The RTN (CORS) technique has one big advantage over postprocessing positioning techniques in forest conditions. It is never known how long the static sessions should last in order to obtain approval results in terms of accuracy and reliability.

It is clear that the time of CORS positioning in forest conditions should be chosen during the best satellite constellation and in the season when there are no leaves on trees. The influence of trees located near the antenna had a strong influence on ambiguity resolution and its reliability. In this study L1 signal processing strategies obtained accurate results as well as L1 and L2 processing strategies.

\section{References}

[1] Andersen, H.-E.; Clarkin T.; Winterberger, K.; Strunk, J. An accuracy assessment of positions obtained using surveygrade and recreational-grade Global Positioning System receivers across a range of forest conditions within the Tanana Valley of Interior Alaska. // Western Journal of Applied Forestry. 24, 3(2009), pp. 128-136.

[2] El-Rabbany, A. Introduction to GPS: The Global Positioning System, Second Edition, Artech House, 2006,pp.159-160.

[3] Kobayashi, H.; Yada, Y.; Chachin, T.; Okano, K.; Nogami, Y.; Torimoto, H. Evaluation of GPS receivers' performance inside and outside forests. // Journal of Japan Forestry Society. 83, (2001), pp.135-142 (in Japanese with English summary).

[4] Landau, H.; Vollath, U.; Chen, X. Virtual Reference Stations versus Broadcast Solutions in Network RTK Advantages and Limitations, Proceedings of GNSS 2003The European Navigation Conference, Graz, Austria, April $22-25,2003$.

[5] Martin, A. A.; Holden, N. M.; Owende, P. M.; Ward, S. M. The effects of peripheral canopy on DGPS performance on forest roads. // International Journal of Forestry Engineering, 12, 1(2001), pp. 71-79.

[6] Mori, A.; Takeda, H. The effects of released S/A on accuracy of DGPS surveying inside the forest. // Journal of Japan Forestry Society. 82, (2000), pp. 393-396 (in Japanese with English summary).

[7] Motosevic, M.; Salcic, Z.; Berber, S. A comparison of accuracy using a GPS and a low-cost DGPS. // IEEE Transactions on Instrumentation and Measurement. 55 5(2006), pp. 1677-1683.DOI: 10.1109/TIM.2006.880918

[8] Nasset, E. Point accuracy of combined pseudo range and carrier phase differential GPS under forest canopy. // Canadian Journal of Forest Research, 29, (1999), pp. 547553. DOI: $10.1139 / \times 99-021$

[9] Naesset, E.; Gjevestad, J. G. Performance of GPS precise point positioning under conifer forest canopies. // Photogrammetric Engineering \& Remote Sensing. 74, (2008), pp. 661-668. DOI: 10.14358/PERS.74.5.661

[10] Pirti, A. Using GPS System near The Forest and Quality Control. // Survey Review Journal. 38, 298(2005), pp. 286298.

[11] Pirti, A. Accuracy Analysis of GPS Positioning near the Forest Environment. // Croatian Journal of Forest Engineering. 29, 2(2008), pp.189-201.

[12] Rizos, C. Alternative to current GPS-RTK services and some implications for CORS infrastructure and operations. // GPS Solution. 11, 3:1(2007), pp. 51-158.

[13] Rodriguez-Perez, J. R.; Alvarez, M. F.; Sanz-Ablanedo, E. Assessment of low-cost GPS receiver accuracy and precision in forest environments. // Journal of Surveying
Engineering. $\quad 133, \quad 4(2007), \quad$ pp. 159-167. DOl: 10.1061/(ASCE)0733-9453(2007)133:4(159)

[14] Sawaguchi, I.; Watanabe, S.; Shishiuchi, M. The effect of stand conditions on positioning precision with real-time DGPS. // Journal of Japan Forestry Society. 16, 1(2001), pp. 35-42 (in Japanese with English summary).

[15] Snay, R. A. Continuously Operating Reference Station (CORS). History, Applications, and Future Enhancements. // Journal of Surveying Engineering. 134, 4(2008), pp. 95104.

[16] Wolf, Pr.; Ghilani, Cd. Elementary Surveying, an Introduction to Geomatics, $12^{\text {th }}$ Edition, Prentice Hall Upper Saddle River, New Jersey, 2008, 960 pages.

[17] Yoshimura, T.; Hasegawa, H. Comparing the precision and accuracy of GPS positioning in forested areas. // Journal of Forest Research. 8, 3(2003), pp. 147-152. DOl: $10.1007 / \mathrm{s} 10310-002-0020-0$

\section{Author's address}

Atinc Pirti, Assoc. Prof. Dr.

Yildiz Technical University, Faculty of Civil Engineering, Department of Geomatics Engineering,

Davutpasa Campus, 34220 Esenler, Istanbul, Turkey

E-mail: atinc@yildiz.edu.tr 